\title{
DIET OF THE YELLOWFIN SNOOK, CENTROPOMUS ROBALITO (ACTINOPTERYGII: PERCIFORMES: CENTROPOMIDAE), IN THE SOUTHWESTERN GULF OF CALIFORNIA
}

\author{
Xchel G. MORENO-SÁNCHEZ ${ }^{1}$, Deivis S. PALACIOS-SALGADO ${ }^{2}$, \\ Leonardo A. ABITIA-CÁRDENAS ${ }^{1}$, José T. NIETO-NAVARRO ${ }^{2 *}$, and Andrés F. NAVIA ${ }^{3}$ \\ ${ }^{1}$ Instituto Politécnico Nacional, Departamento de Pesquerías y Biología Marina, La Paz, BCS, México \\ ${ }^{2}$ Escuela Nacional de Ingeniería Pesquera-Universidad Autónoma de Nayarit, San Blas, Nayarit, México \\ ${ }^{3}$ Fundación Colombiana para la Investigación y Conservación de Tiburones y Rayas, Cali, Colombia
}

Moreno-Sánchez X.G., Palacios-Salgado D.S., Abitia-Cárdenas L.A., Nieto-Navarro J.T., Navia A.F. 2015. Diet of the yellowfin snook, Centropomus robalito (Actinopterygii: Perciformes: Centropomidae), in the southwestern Gulf of California. Acta Ichthyol. Piscat. 45 (1): 21-29.

\begin{abstract}
Background. The yellowfin snook, Centropomus robalito Jordan et Gilbert, 1881, is one of the most important species in southwestern Gulf of California fisheries. It is caught in estuarine systems by coastal fishermen and as bycatch on the continental platform, by the industrial shrimp fishery. Dietary analysis are important to understanding the trophic interactions and the position of species within a foodweb and to understand the dynamics of marine communities. In this study, we describe the diet of the yellowfin snook in the southwestern Gulf of California and quantify the effects of sex and size on the species' diet.

Materials and methods. Stomachs of $C$. robalito were obtained from the shrimp fishery that operates off the southwestern Gulf of California. Percentages by number, weight, and frequency of each food category were determined, and the index of relative importance (\%IRI) was calculated to define the main food categories. Diet breadth and diet similarity between sexes and among sizes were also calculated.

Results. A total of 401 stomachs were inspected, of which practically all $(n=385 ; 96 \%)$ contained food. According to \%IRI, the main prey consumed comprised the shrimp Trachypenaeus pacificus (73\%), Xiphopenaeus riveti (10\%), and Penaeus spp. (7\%). Secondary items included: the stomatopod Squilla mantoidea $(4 \%)$, Unidentified organic matter (UOM, $3 \%$ ), and the fish Porichthys sp. $(2 \%)$. Centropomus robalito is a specialist predator with a low diet Breadth value $\left(B_{i}=0.14\right)$. While there were no significant differences in diet between the sexes (Analysis of similarities [ANOSIM]; $R=0.014 ; P=0.50$ ), there were differences among sizes (ANOSIM, $R=0.361 ; P=0.01$ ).

Conclusion. Centropomus robalito is a second-order predator that feeds mainly on shrimp, which are abundant throughout its distribution area. The feeding strategy of $C$. robalito fits the optimal foraging theory. This fish feeds on the most abundant species, obtaining a higher energetic benefit than it would obtain from less available prey, or from more mobile and larger prey that would imply expending more energy in the search, attack, and manipulation of these prey.
\end{abstract}

Keywords: predator, trophic level, bycatch, ontogenetic changes, shrimp, Trachypenaeus pacificus

\section{INTRODUCTION}

Information on the diet of fish is necessary to understand their role in trophic webs in a given space and time (Gerkin 1994). The diet of predators is influenced by multiple factors, such as prey availability, mobility, abundance, environmental factors, and the developmental stage and sex of the predator, which have been identified as determinant of the ecological importance of each species in the trophic web in which they participate (Braga et al. 2012, Navia et al. 2012).
Species of the genus Centropomus are characterized as being active nocturnal predators that feed on crustaceans and coastal fish (Adams et al. 2009, FeltrinContente et al. 2009). The yellowtail snook, Centropomus robalito Jordan et Gilbert, 1882, is the most abundant species of the Centropomidae family captured as bycatch in shrimp fishery of the southwestern Gulf of California. It also represents one of the most important artisanal fisheries, traditionally being caught by coastal fishing communities in the Mexican states of Nayarit and Sinaloa

\footnotetext{
* Correspondence: Dr. José T. Nieto Navarro, Escuela Nacional de Ingeniería Pesquera, Colección Ictiológica, Apdo. Postal 10, C.P. 63740 San Blas, Nayarit, México, phone: (+52) (323) 231 2120, e-mail: (XGMS) xchel.moreno@gmail.com, (JTNN) nieto@uan.edu.mx, (DSPS) palaciossalgado@gmail.com, (LAAC) laabitia@gmail.com, (AFN)anavia@squalus.org.
} 
(Ulloa-Ramírez et al. 2008, Nieto-Navarro et al. 2010, Bohórquez Herrera unpublished*). The species is distributed from the Gulf of California south to Peru. It inhabits estuaries and bays, but can also move up freshwater channels (Robertson and Allen 2008).

According to fishery statistics the fishery of the snook (Centropomus spp.) has been declining since the 1990s; thus, it has been categorized as an exploited species (Arreguín-Sánchez and Arcos-Huitrón 2011). However, despite the growing fishing pressure to which the yellowfin snook is indirectly subjected (Ulloa-Ramírez et al. 2008), there is little information on its basic biology and even less information on its trophic ecology. In this study, we describe the diet of the yellowfin snook, its feeding strategy, and the effect of sex and size on the diet, in order to determine its trophic interactions.

\section{MATERIALS AND METHODS}

Samples were taken during fall 2012 from shrimptype trawls carried out in the area between Piedra del Asadero $\left(21^{\circ} 34.843^{\prime} \mathrm{N}, 105^{\circ} 30.590^{\prime} \mathrm{W}\right)$ and San Blas $\left(21^{\circ} 31.978^{\prime} \mathrm{N}, 105^{\circ} 20.616^{\prime} \mathrm{W}\right)$ (Fig. 1). This area is characterized by the presence of soft bottoms of sandy mud and waters $8.5-15 \mathrm{~m}$ deep. Samples were frozen and transported to the Trophic Ecology Laboratory of the Escuela Nacional de Ingeniería Pesquera, where measurements such as Standard length (SL) and Total weight (TW) were taken and where stomachs were extracted. During stomach content analysis, food items were categorized in taxonomic groups and subsequently items were identified to the lowest taxon possible, depending on prey digestion state. The works of Brusca (1980) and Morris et al. (1980) were used to identify crustaceans and mollusks, and Fischer et al. (1995), to identify fishes.

To determine whether the stomachs analyzed were truly representative of the yellowfin snook diet, an accumulated diversity curve (EstimateS Swin820; Colwell 2009) was calculated based on the value of the Shannon-Weaver diversity index $\left(H^{\prime}\right)$ for each stomach. Coefficient of variation (CV) was calculated to obtain quantitative information of the number of stomachs that were adequate and representative of the diet. If $\mathrm{CV}$ was $\leq 5 \%(0.05)$, the number of stomachs examined was considered adequate (JiménezValverde and Hortal 2003, Hernández-Aguilar et al. 2013).

To characterize the diet, percentage Frequency of occurrence $(\% F)$, percentage by Number $(\% N)$, and percentage by Weight $(\% W)$ were calculated. The main food categories were defined according to Index of Relative Importance (IRI) proposed by Pinkas et al. (1971) and modified by Hacunda (1981) as follows:

$$
\mathrm{IRI}=(\% N+\% W) \times \% F
$$

This index combines the information from the previous indices and determines the contribution of each prey item to the predator's diet (Liao et al. 2001). For comparisons with previous studies, we also employed the standardized IRI percentage (\%IRI) (Cortés 1997) as follows:

$$
\% \mathrm{IRI}_{\mathrm{i}}=\frac{100 \times \mathrm{IRI}_{\mathrm{i}}}{\sum \mathrm{IRI}_{\mathrm{i}}}
$$

The diet was also compared between sexes (males and females) and among size classes (small, medium, and large). Because size at maturity of the yellowtail snook is unknown, we utilized Sturges' rule (Sturges 1926) to determine size intervals in order to evaluate possible changes in the diet with size.

The diet Breadth $\left(B_{i}\right)$ was calculated using the Levin standardized index (Hurlbert 1978), with \%IRI values expressed as a proportion. The Levin index considers values from 0 through 1 . When $B_{i}$ values are near zero, the predator is considered a specialist, while values near one

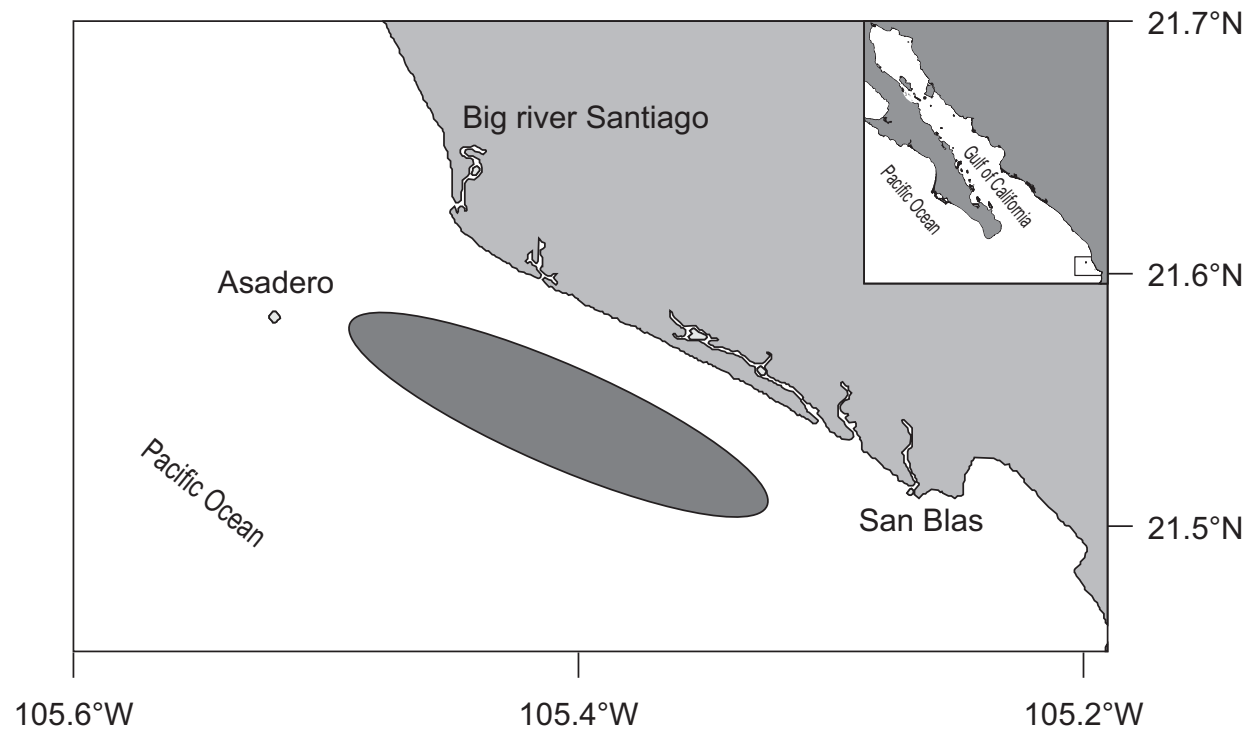

Fig. 1. Study area. The ellipse indicates the area where fishing trawls were carried out 
indicate a generalist predator (Krebs 1999). To calculate this index, the following equation was used:

$$
\mathrm{B}_{\mathrm{i}}=\frac{\left(\frac{1}{\sum \mathrm{p}_{\mathrm{j}}^{2}}-1\right)_{\mathrm{i}}}{(\mathrm{n}-1)}
$$

where $B_{i}$ is the niche Breadth, $\sum p^{2}$ is the proportion of the $j$ item in predator $i$ diet, and $n$ is the total number of prey items.

To interpret the species' feeding strategy and to establish patterns of population or individual dietary specialization, we employed Costello's graph (Amundsen et al. 1996), while to evaluate the possible effects of sex and size on diet, we used a Non-metric multidimensional analysis (NMDS). Analysis of similarities (one-way Analysis of similarities [ANOSIM], with 999 permutations) was utilized to test for differences in diet according to sex and size (Dale et al. 2011). The resulting $R$ statistic $(-1<R<1)$ describes the similarity between groups defined according to the previously mentioned factors. Values near zero indicate no difference, and values near 1 or near -1 indicate a signification separation between groups.

Data preparation for multivariate analysis was carried out according to White et al. (2004) and to Marshall et al. (2008). Namely, dietary data for a single individual contained large numbers of zero values, giving rise to instabilities in the calculation of similarities at an individual level, which greatly reduces the effectiveness of multivariate analyses of dietary data. This problem was efficiently minimized by averaging the dietary data $(\% W)$ for groups of individuals to produce a new series of replicates for a given factor (i.e., species or length class or sex). Prior to performing multivariate analyses, $\% W$ data for dietary categories of each subset (i.e., replicate) were square roots transformed and used to construct the Bray-Curtis resemblance matrix for non-metric Multidimensional scaling (nMDS) ordination and a one-way ANOSIM test (Clarke and Gorley 2006).

To determine trophic level $\left(\mathrm{TL}_{k}\right)$ of the yellowtail snook from the type of prey $(k)$ found in stomach contents, we used the equation proposed by Cortés (1999) as follows:

$$
\mathrm{TL}_{\mathrm{k}}=1+\left(\sum_{\mathrm{i}=1}^{\mathrm{n}} \mathrm{p}_{\mathrm{j}} \times \mathrm{TL}_{\mathrm{j}}\right)
$$

where $\mathrm{TL}_{j}$ is the trophic level of each prey category $j$, and $p_{j}$ is the proportion of each prey category in the diet. The trophic level of each prey category was based on Cortés (1999) and on López-García et al. (2012).

\section{RESULTS}

Centropomus robalito captured for stomach analysis measured between 11.7 and $25 \mathrm{~cm}$ standard length and weighed between 25.8 and $307 \mathrm{~g}$. A total of 401 stomachs were examined, of which 385 (96\%) contained food. According to the $\mathrm{CV}$, the accumulated prey diversity curve reached its asymptote at 130 stomachs, which indicates that the number of stomachs analyzed was sufficient to represent the diet (Fig. 2).

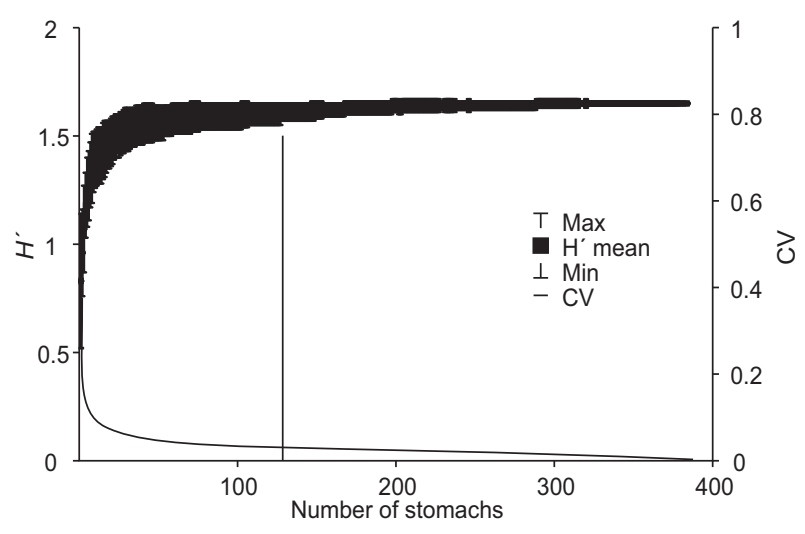

Fig. 2. Diversity curve of random prey of yellowfin snook, Centropomus robalito; Shannon-Weaver diversity $\left(H^{\prime}\right)$; Max $=$ maximal diversity, $\operatorname{Min}=$ minimal diversity, $\mathrm{CV}=$ coefficient of variation

The diet comprised 24 prey items (species/taxa), including bivalves (1), shrimp (6), stomatopods (3), fish (12), crabs (1), and Unidentified organic matter (UOM). The TW of stomach contents was $380.65 \mathrm{~g}$, of which the zebra shrimp, Trachypenaeus pacificus, represented 38\% (144 g), the shrimp Xiphopenaeus riveti-16\% (60 g), and Penaeus spp.-11\% (41 g). The stomatopod Squilla mantoidea represented 7\% (25 g) of the TW, UOM-6\% (24 g), and the fish Porichthys spp.—5\% (20 g) (Table 1).

A total of 507 prey organisms were counted. The most abundant prey were Trachypenaeus pacificus $(42 \% ; n=216)$, Xiphopenaeus riveti $(15 \% ; n=77)$, Penaeus spp. (13\%; $n=65)$, Squilla mantoidea $(10 \% ; n=38)$, and Porichthys spp. $(5 \% ; n=25)$ (Table 1$)$.

The most frequent prey items were the shrimp T. pacificus $(36 \% ; n=139)$, UOM $(18 \% ; n=68)$, the shrimp $X$. riveti $(12 \% ; n=47)$, and Penaeus spp. $(11 \% ; n=44)$, the stomatopod $S$. mantoidea $(10 \% ; n=38)$, and the fish Porichthys spp. $(6 \% ; n=24)$ (Table 1).

The Index of relative importance (\%IRI) indicated that the most important prey in the diet of the yellowtail snook were the shrimp $T$. pacificus $(73 \%)$, the shrimp $X$. riveti (10\%), and Penaeus spp. (7\%), the stomatopod S. mantoidea (4\%), UOM (3\%), and the fish Porichthys spp. $(2 \%)$. The remaining food components comprised $2 \%$ of the index (Table 1).

Of 385 stomachs containing food, 216 were obtained from males and 169 from females. The male diet comprised 17 food items. The most important prey items according to the \%IRI were the shrimp $T$. pacificus (71\%), the stomatopod S. mantoidea (10\%), the shrimp Penaeus spp. (7\%), and $X$. riveti (4\%), UOM (4\%), and the fish Porichthys spp. (1\%) (Fig. 3a). Females consumed 19 food items, of which the most important were the shrimp T. pacificus $(40 \%), X$. riveti $(20 \%)$, and Penaeus spp. (12\%), the fish Porichthys spp. (5\%), and Anchoa lucida (Jordan et Gilbert, 1882) (4\%) (Fig. 3b).

Because the size at maturity of yellowtail snook is unknown, we used Sturges' rule to determine the size intervals in order to evaluate possible changes in the diet 
with size. Size intervals included small (11-16 cm SL), medium (17-21 cm SL), and large (22-23 cm SL).

A total of 130 small-sized fish were caught, which fed on 11 food items. The most important prey according to the \%IRI were the shrimp Trachypenaeus pacificus (72\%), the stomatopod Xiphopenaeus mantoidea (11\%), UOM (4\%), and the shrimp Penaeus spp. (4\%). A total of 236 medium-sized fish were caught, which fed on 22 food components. The most important prey in the diet were the shrimp T. pacificus (71\%), X. riveti (13\%), and Penaeus spp. (9\%), and UOM (2\%) (Fig. 3d). There were only 19 large-size fish caught, which fed on eight food items, and the most important prey were the shrimp T. pacificus (76\%), X. riveti (11\%), and Penaeus spp. (3\%) (Fig. 3e). There were no significant differences in diet between the sexes (ANOSIM, $R=0.014 ; P=0.50$ ), while there were differences among sizes (ANOSIM, $R=0.361 ; P=0.01$ ) (Fig. 4a, b) (Table 2).

The yellowtail snook is a predator with a specialist tendency $\left(B_{i}=0.14\right)$. This behavior was observed in males as well as females $\left(B_{i}=0.20 ; B_{i}=0.16\right)$ and in the three size class intervals $\left(B_{i}=0.18 ; B_{i}=0.15\right.$, and $\left.B_{i}=0.43\right)$. The species' feeding strategy confirmed that the yellowtail snook is a specialist predator and the most important prey were the shrimp (T. pacificus, X. riveti, and Penaeus spp.) (Fig. 5). The trophic level calculated for the species and for each sex was 3.8. Trophic level was 3.8 for small fish, 3.8 for medium fish, and 2.8 for large fish.

\section{DISCUSSION}

The high percentage of stomachs with food contents (96\%) obtained during the study period could be attributed to the timing of the fishery, which was carried out at dawn (0400-0800 h). This time period has been reported as a time of high feeding intensity for this species; it increases during the night and decreases during the day (Bohórquez Herrera unpublished*). This is corroborated by the presently reported study, because the majority of prey species were not at advanced states of digestion, indicating that the food had been recently ingested.

Table 1

Detailed characteristics of individual food components in diet of yellowfin snook, Centropomus robalito

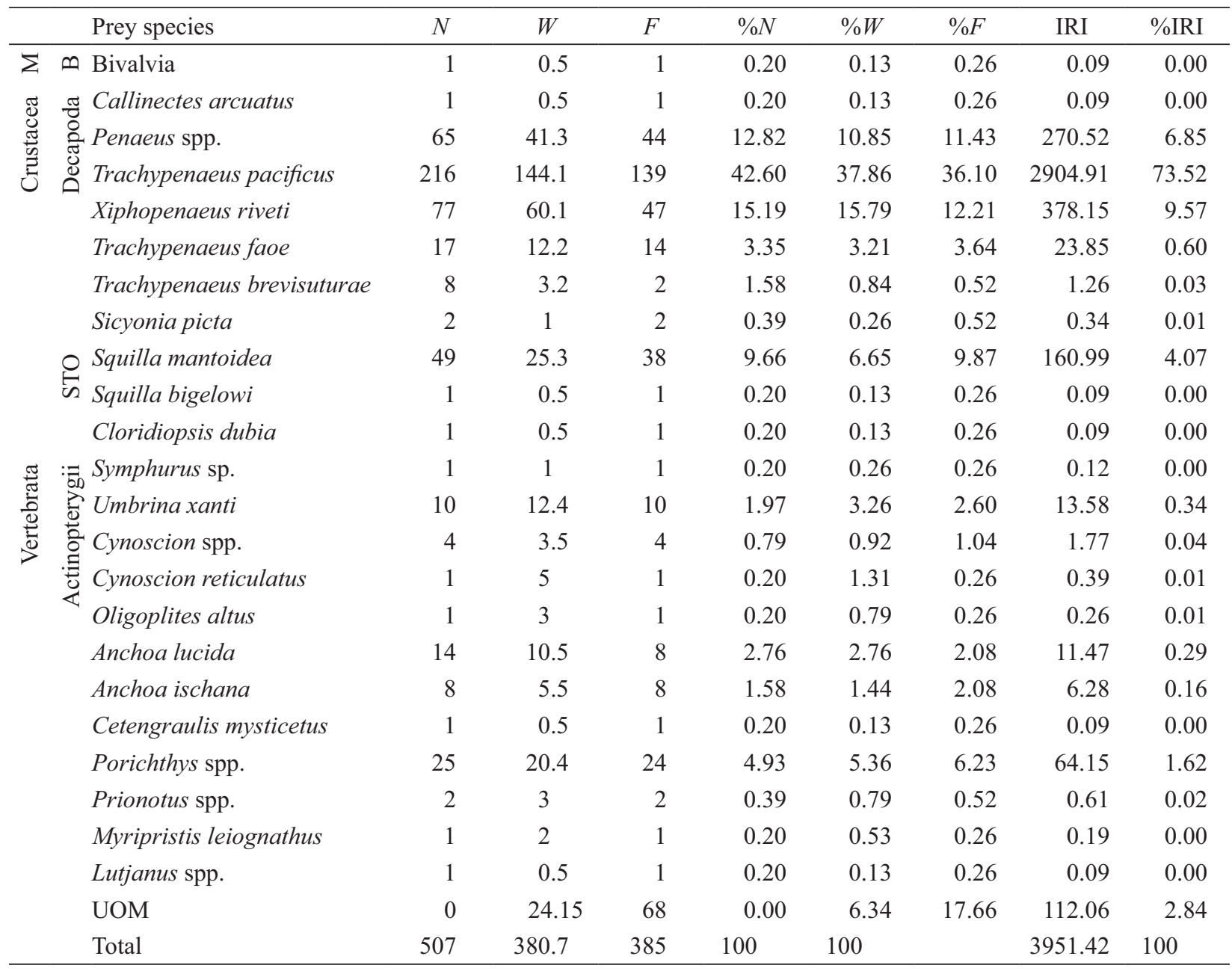

$\mathrm{M}=$ Mollusca, $\mathrm{B}=$ Bivalvia, $\mathrm{STO}=$ Stomatopoda; Absolute and percentage values given for: $N=$ number, $W=$ weight, $F=$ frequency of occurrence, $\mathrm{IRI}=$ index of relative importance, $\mathrm{UOM}=$ unidentified organic matter.

\footnotetext{
* See footnote on page 22 .
} 
According to the results of this study, Centropomus robalito is a carnivorous carcinophagous predator that feeds mainly on shrimp, with low consumption of fish and stomatopods. This feeding behavior has been reported in general for species of the Centropomidae family (Orrell 2002, Robertson and Allen 2008). Other congeners such as: Centropomus undecimalis (Bloch, 1792); Centropomus parallelus Poey, 1860; Centropomus pectinatus Poey, 1860; Centropomus nigrescens Günther, 1864; and Centropomus poeyi Chávez, 1961 feed on a variety of invertebrates, mainly shrimp (Penaeus, Sicyonnidae, and Palaemonetes), fish (Engraulidae, Mugilidae, Lutjanidae, Cynoglossidae, Clupeidae, and fish eggs), crabs
(Callinectes, Portunus, Xanthidae, and Euphylax), stomatopods (Hemisquillidae and Squillidae), polychaetes (Polychaeta), bivalves (Bivalvia), sea stars (Ophiuroidea), and detritus (Chávez 1963, Cervigón 1966, Carvajal 1975, Yáñez-Arancibia 1978, Adams et al. 2009, FeltrinContente et al. 2009).

Specific studies of the feeding habits of Centropomus robalito reported that it feeds mainly on shrimp (Penaeus spp.), fish, stomatopods, isopods, and crab in the coastal lagoons of Sinaloa, Mexico (Díaz-González and Soto 1987). For the continental platform of Nayarit, Bohórquez Herrera (unpublished*) reported that the yellowtail snook diet was dominated by shrimp (Solenocera mutator and
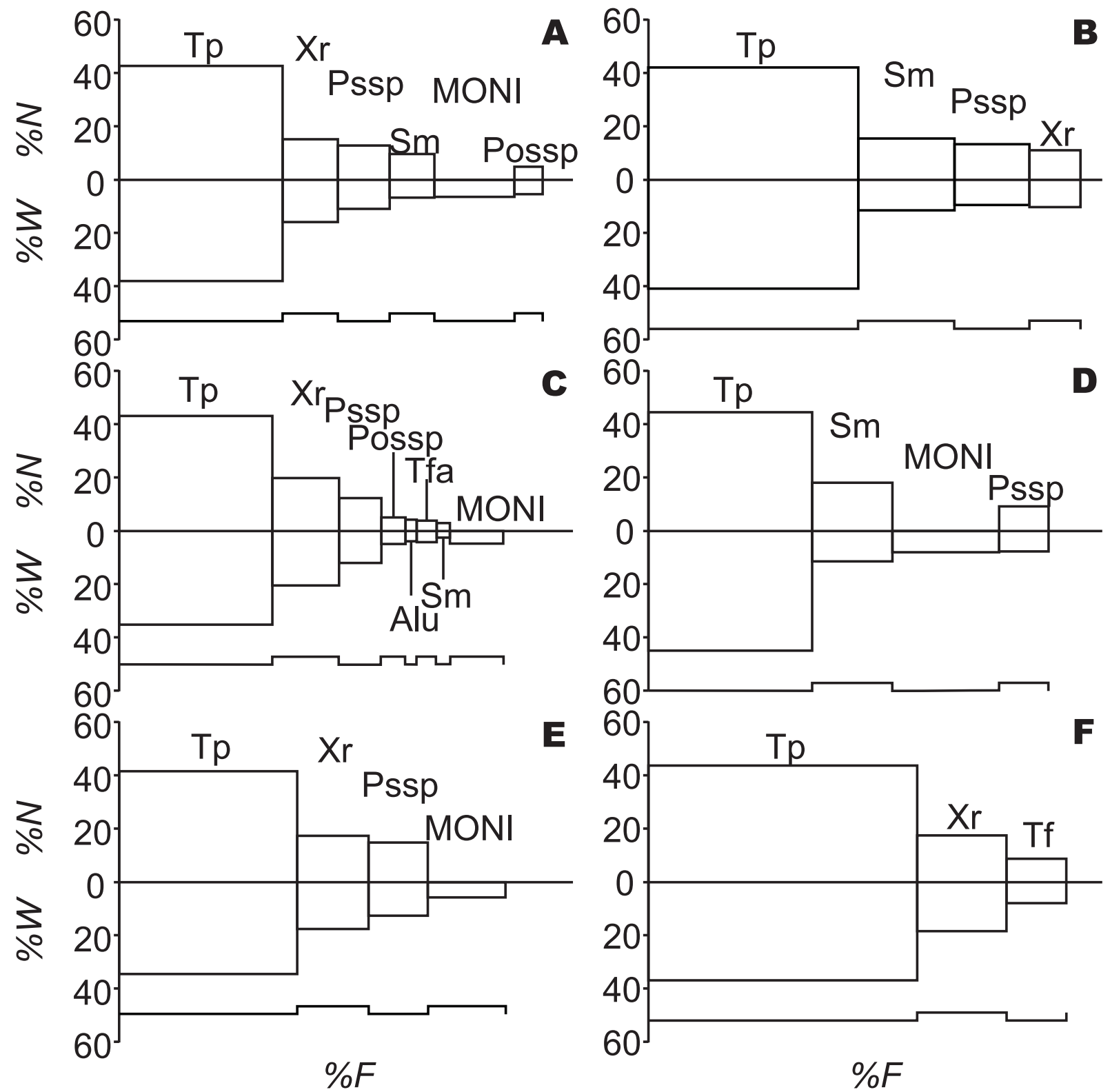

Fig. 3. Variation of prey species consumed by the yellowfin snook, Centropomus robalito, determined with the Index of Relative Importance (IRI): A, general; B, males; C, females; D, small sizes; E, medium sizes; F, large sizes; $\mathrm{Tp}=$ Trachypenaeus pacificus, $\mathrm{Xr}=$ Xiphopenaeus riverti, $\mathrm{Pspp}=$ Penaeus $\mathrm{spp}, \mathrm{Sm}=$ Squilla mantoidea, $\mathrm{UOM}$ $=$ unidentified organic matter, Pospp = Porichthys spp, Alu = Anchoa lucida, Tfa = Trachypenaeus faoe, $\% N=$ percentage by number, $\% W=$ percentage by weight), $\% F=$ percentage frequency of occurrence 
Farfantopenaeus californiensis), with a lower proportion of fish (Anchoa spp.; Engraulis mordax Girard, 1854; and Lutjanus guttatus (Steindachner, 1869)) and stomatopods (Squilla biformis). Franco Moreno (unpublished*), for the continental platform of Nayarit-Sinaloa, reported a high abundance of shrimp (Solenocera spp.) and stomatopods (Squilla biformis) in stomach contents. As it is evident from available sources, the carcinophagous feeding pattern of $C$. robalito is constant on the Mexican Pacific (coasts of Sinaloa and Nayarit), with main prey species being shrimp, fish, and stomatopods. Although the identity of the prey species changes, this could be due to the environmental conditions under which these fish feed. For example, in the continental platform areas of Sinaloa and Nayarit where waters are deeper, the yellowtail snook feeds on shrimp from the genus Solenocera, which are abundant at depths $>100 \mathrm{~m}$, while in coastal lagoons, it feeds on shrimp of the Penaeus genus, which are mainly distributed throughout shallow depths $(<40 \mathrm{~m})$ (DíazGonzález and Soto 1987, Fischer et al. 1995, Bohórquez Herrera unpublished**, Franco Moreno unpublished*). This suggests that $C$. robalito plays similar trophic roles in the different marine environments in which it is found, and that it makes use of similar species within certain prey groups, such as crustaceans.

There were no significant differences in diet between the sexes due to the high consumption of shrimp, stomatopods, and fish, which together made up $90 \%$ of the diet. This result could be due to a lack of sex segregation during feeding. The differences found among size classes could be due to a slight increase in fish consumption-Anchoa lucida, Prionotus spp., and Anchoa ischana (Jordan et Gilbert, 1882) - at larger fish sizes. This behavior has been reported for other species of this family. Feltrin-Contente et al. (2009) identified ontogenetic changes in the diet of Centropomus parallelus, which changed from tanaids to shrimp or fish. Aliaume et al. (1997) found that small-sized Centropomus ensiferus Poey, 1860, C. parallelus, and C. undecimalis fed mainly on shrimp, and when they grew they incorporated a higher percentage of fish into their diet. These ontogenetic changes in the diet of fish have been attributed to the increase in energetic requirements, as well as to a higher ability to hunt and manipulate their prey, which affords them greater success in prey capture (Abitia-Cárdenas 1997, Lemos et al. 2006).

The specialist feeding strategy of Centropomus robalito was previously reported by Bohórquez Herrera (unpublished**) and Franco Moreno (unpublished*) as being based on preferential consumption of shrimp. This behavior could be encouraged by the great abundance of this prey in the study area, in which approximately $60 \%$ of the global production of the shrimp fishery is accounted for by the species Trachypenaeus pacificus, Xiphopenaeus riveti, and Penaeus spp. (Hendrickx 1984, Barbosa-Saldaña et al. 2012). According to the optimal foraging theory, $C$. robalito feeds on the most abundant prey, thus obtaining a higher energetic benefit than it would obtain from foraging on less available or more mobile prey, which would imply a higher energy expenditure from searching, attacking, and handling the prey (Gerking 1994).
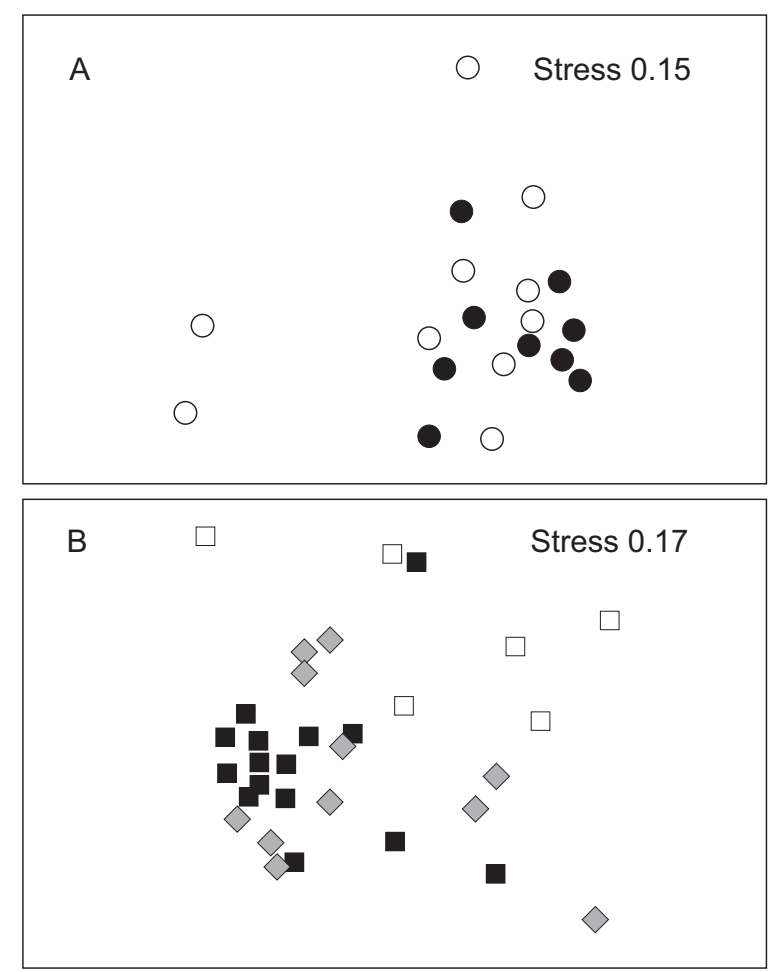

Fig. 4. Non-metric multidimensional scaling analysis (NMDS) of percentage by number $(\% N)$ data in the diet of yellowfin snook, Centropomus robalito, based on sex: $\circ=$ males, $\bullet=$ females; and size: $\diamond=$ small, $\mathbf{\square}=$ medium, $\square=$ large

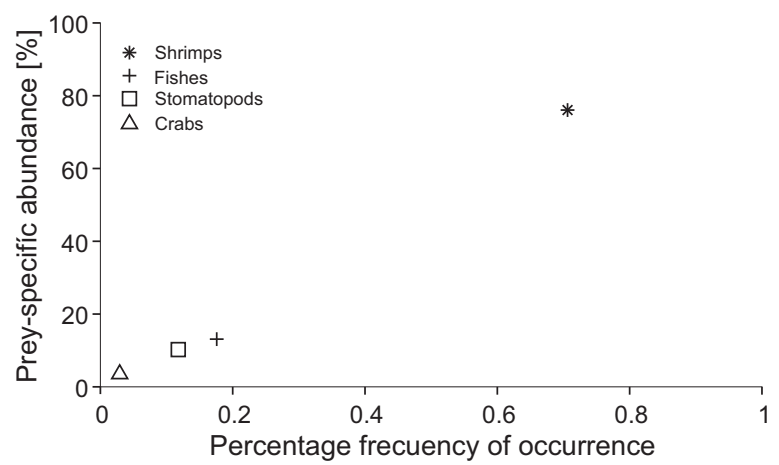

Fig. 5. Costello's graph. Numerical abundance of prey species by percentage frequency of occurrence $(\% F)$ in the general diet of yellowfin snook, Centropomus robalito

The trophic level determined for the species (3.8), its specialized diet, and its function as prey in the diet of larger predators (e.g., Carcharhinus spp.) indicate that

\footnotetext{
* Franco Moreno R.A. 2011. Morfología y desempeño del aparato mandibular de seis especies de peces ictiófagos demersales, asociados a los fondos blandos de la plataforma continental de Nayarit-Sinaloa. Tesis de Maestría. CICIMAR-IPN. La Paz, Baja California Sur, México.

${ }^{* *}$ See footnote on page 22
} 
Table 2 $R$ and $P$ significance values for diet similarity analyses (Analysis of similarities [ANOSIM]) between sexes and among sizes of yellowfin snook, Centropomus robalito

\begin{tabular}{lcc}
\hline \multirow{2}{*}{ Combination } & \multicolumn{2}{c}{ ANOSIM } \\
\cline { 2 - 3 } & $R$ & $P$ \\
\hline Females vs. males & 0.004 & 0.417 \\
Small vs. medium & 0.096 & 0.075 \\
Small vs. large & 0.351 & $0.005^{\mathrm{s}}$ \\
Medium vs. large & 0.680 & $0.001^{\mathrm{s}}$ \\
\hline
\end{tabular}

$\mathrm{S}$ significant values for diet similarity analyses.

Centropomus robalito occupies an important place in intermediate trophic web levels, and that it participates actively in energy flow within the web (Yáñez-Arancibia 1978, Zetina-Rejón et al. 2003). There are other fish species in the study area, such as Centropomus armatus Gill, 1863; Centropomus medius Günther, 1864; Caulolatilus affinis Gill, 1865; Lutjanus peru (Nichols et Murphy, 1922); Lutjanus guttatus; Pomadasys panamensis (Steindachner, 1876); and Pseudupeneus grandisquamis (Gill, 1863), which feed on a variety of invertebrates, especially crustaceans and fish, and that have similar trophic levels (3.5-3.99) (Díaz-González and Soto 1987, Bohórquez Herrera unpublished*, Franco Moreno unpublished**, Palacios Salgado unpublished***). This suggests a possible interspecific competition, but apparently the high abundance of the main prey species (shrimp, stomatopods, and fish), as well as the use of each prey item at different proportions by the predators (trophic plasticity), the different feeding times, as well as morphological differences, allow the coexistence of these predators (Díaz-González and Soto 1987, Cruz-Escalona et al. 2000, Bohórquez Herrera unpublished*, Franco Moreno unpublished**).

Finally, the results of this study show that Centropomus robalito is a species that participates actively in the processes of dispersion of indirect trophic effects in the trophic web, and that also forms redundant trophic groups, which suggests that it could be a species with high structural and functional value for trophic web stability in the study area (Menge 1995, Navia et al. 2012).

\section{ACKNOWLEDGEMENTS}

All of the authors are grateful for economic support provided by the projects SIP-IPN (20130869) and CONACyT (Clave 205024). We gratefully thank the Unidad Académica Escuela Nacional de Ingeniería Pesquera (UAN-ENIP) for providing us with the specimens. XG-MS thanks the Instituto Politécnico Nacional (IPN) for economic support through the Contratación por Excelencia Program. XG-MS and LA-AC are grateful for support received through COFAA and EDI. This project was made possible by agre- ements made through the Red Interinstitucional para la Evaluación, Manejo y Aprovechamiento de los Recursos Acuáticos (RIEMARA). We thank Laura Sampson for editing the English version of this manuscript.

\section{REFERENCES}

Abitia-Cárdenas L.A., Galván F., Rodríguez J. 1997. Food habits and energy values of prey of striped marlin, Tetrapturus audax, off the coast of Mexico. Fishery Bulletin 95 (2): 360-368.

Adams A.J., Wolfe R.K., Layman C.A. 2009. Preliminary examination of how human-driven freshwater flow alteration affects trophic ecology of juvenile snook (Centropomus undecimalis) in estuarine creeks. Estuaries and Coasts 32 (4): 819-828.

DOI: $10.1007 / \mathrm{s} 12237-009-9156-\mathrm{x}$

Aliaume C., Zerbi A., Miller J.M. 1997. Nursery habitat and diet of juvenile Centropomus species in Puerto Rico estuaries. Gulf of Mexico Science 15 (2): 77-87.

Amundsen P.A., Gabler H.M., Staldvik F.J. 1996. A new approach to graphical analysis of feeding strategy from stomach contents data-modification of the Costello (1990) method. Journal of Fish Biology 48 (4): 607-614. DOI: $10.1111 / \mathrm{j} .1095-8649.1996 . t b 01455 . x$

Arreguín-Sánchez F., Arcos-Huitrón E. 2011. La pesca en México: estado de la explotación y uso de los ecosistemas. Hidrobiológica 21 (3): 431-462.

Barbosa-Saldaña M.L., Díaz-Jaimes P., Uribe-Alcocer M. 2012. Variación morfológica del camarón café (Farfantepenaeus californiensis) en el Pacífico mexicano. Revista Mexicana de Biodiversidad 83 (1): 42-50.

Braga R.R., Bornatowski H., Vitulé J.R.S. 2012. Feeding ecology of fishes: An overview of worldwide publications. Reviews in Fish Biology and Fisheries 22 (4): 915-929.

DOI: $10.1007 / \mathrm{s} 11160-012-9273-7$

Brusca R.C. 1980. Common intertidal invertebrates of the Gulf of California. 2nd edn. University of Arizona Press. Tucson, AZ, USA.

Carvajal J. 1975. Contribución al conocimiento de la biología de los robalos Centropomus undecimalis y C. poeyi en la Laguna de Términos, Campeche, México. Boletín del Instituto Oceanográfico de Venezuela de la Universidad de Oriente 14 (1): 51-70.

Cervigón F. 1966. Los peces marinos de Venezuela. Estación de Investigaciones Marinas de Margarita. Monografías 1 y 2. Carácas, Venezuela: Fundación La Salle de Ciencias Naturales.

Chávez M. 1963. Contribución al conocimiento de la biología de los robalos, chucumite y constantino (Centropomus spp.) del estado de Veracruz (Pisces; Centropomidae). Ciencia México 22 (5): 141-160.

Clarke K.R., Gorley R.N. 2006. PRIMER v6 User Manual/Tutorial. Primer-E, Plymouth, UK.

\footnotetext{
${ }^{*}$ See footnote on page 22 .

${ }^{* *}$ See footnote on page 26

*** Palacios Salgado D.P. 2011. Patrones latitudinales de composición y diversidad funcional de peces asociados a la pesca de camarón del Pacífico mexicano. Tesis de Doctorado. CICIMAR-IPN. La Paz, Baja California Sur, México.
} 
Colwell R.K. 2009. EstimateS: Statistical Estimation of Species Richness and Shared Species from Samples. Version 8.2, URL http://viceroy.eeb.uconn.edu/estimates

Cortés E. 1997. A critical review of methods of studying fish feeding based on analysis of stomach contents: Application to elasmobranch fishes. Canadian Journal of Fisheries and Aquatic Sciences 54 (3): 726-738. DOI: $10.1139 / \mathrm{f} 96-316$

Cortés E. 1999. Standardized diet compositions and trophic levels of sharks. ICES Journal of Marine Science 56 (5): 707-717.

DOI: $10.1006 /$ jmsc. 1999.0489

Cruz-Escalona V.H., Abitia-Cardenas L.A., CamposDávila L., Galvan-Magaña F. 2000. Trophic interrelations of the three most abundant fish species from Laguna San Ignacio, Baja California Sur, Mexico. Bulletin of Marine Science 66 (2): 361-373.

Dale J.J., Wallsgrove N.J., Popp B.N., Holland K. 2011. Nursery habitat use and foraging ecology of the brown stingray Dasyatis lata determined from stomach contents, bulk and amino acid stable isotopes. Marine Ecology Progress Series 433: 221-236.

Díaz González G., Soto L.A. 1988. Hábitos alimenticios de peces depredadores del sistema lagunar HuizacheCaimanero, Sinaloa, México. Anales del Instituto de Ciencias del Mar y Limnología 15: 97-123.

Feltrin-Contente R., Freitas-Stefanoni M., Gadig O.B.F. 2009. Size-related shifts in dietary composition of Centropomus parallelus (Perciformes: Centropomidae) in an estuarine ecosystem of the southeastern coast of Brazil. Journal of Applied Ichthyology 25 (3): 335-342. DOI: $10.1111 / \mathrm{j} .1439-0426.2008 .01179 . x$

Fischer W., Krupp F., Schneider W., Sommer C., Carpenter K.E., Niem V.H. 1995. Guía FAO para la identificación de especies para los fines de pesca, Pacífico Centro-Oriental. Vol. 2 and 3. Vertebrados- Partes 1 and 2. FAO, Roma.

Gerking S.D. 1994. Feeding ecology of fish. Academic Press, San Diego, CA, USA.

Hacunda J.S. 1981. Trophic relationships among demersal fishes in a coastal area of the Gulf of Maine. Fishery Bulletin 79 (4): 775-788.

Hendrickx M.E. 1984. The species of Sicyonia H. Milne Edwards (Crustacea: Penaeoidea) of the Gulf of California, Mexico, with a key for their identification and a note on their zoogeography. Revista Biología Tropical 32: 279-298.

Hernández-Aguilar S.B., Abitia-Cárdenas L.A., MorenoSánchez X.G., Arellano-Martínez M., GonzálezRodríguez E. 2013. Trophic spectrum of the sailfish Istiophorus platypterus caught off Acapulco in the southern Mexican Pacific. Journal of the Marine Biological Association of the United Kingdom 93 (4): 1097-1104. DOI: $10.1017 / \mathrm{S} 0025315412001622$

Hurlbert S.H. 1978. The measurement of niche overlap and some relatives. Ecology 59 (1): 67-77.

DOI: $10.2307 / 1936632$

Jiménez-Valverde A., Hortal J. 2003. Las curvas de acumulación de especies y la necesidad de evaluar la calidad de los inventarios biológicos. Revista Ibérica de Aracnología 2008 (8): 151-161.

Krebs C.J. 1999. Ecological Methodology. Addison Wesley Educational Publishers, Menlo Park, CA, USA.

Lemos D., Netto B., Germano A. 2006. Energy budget of juvenile fat snook Centropomus parallelus fed live food. Comparative Biochemistry and Physiology, Part A: Molecular and Integrative Physiology 144 (1): 33-40. DOI: $10.1016 /$ j.cbpa.2006.01.028

Liao H., Pierce C.L., Larscheid J.G. 2001. Empirical assessment of indices of prey importance in the diets of predacious fish. Transactions of the American Fisheries Society 130 (4:) 583-591.

DOI: 10.1577/1548-8659(2001)130<0583:EAOIOP $>2.0 . C O ; 2$

López-García J., Navia A.F., Mejía-Falla P.A., Rubio E.A. 2012. Feeding habits and trophic ecology of Dasyatis longa (Elasmobranchii: Myliobatiformes): sexual, temporal and ontogenetic effects. Journal of Fish Biology 80 (5): 1563-1579. DOI: $10.1111 / \mathrm{j} .1095-8649.2012 .03239 . x$

Marshall A.D., Kyne P.M., Bennett M.B. 2008. Comparing the diet of two sympatric urolophid elasmobranchs (Trygonoptera testacea Müller \& Henle and Urolophus kapalensis Yearsley \& Last): Evidence of ontogenetic shifts and possible resource partitioning. Journal of Fish Biology 72 (4): 883-898.

DOI: $10.1111 / j .1095-8649.2007 .01762 . x$

Menge B. 1995. Indirect effects in marine rocky intertidal interaction webs: patterns and importance. Ecological Monographs 65 (1): 21-74.

DOI: $10.2307 / 2937158$

Morris R.C., Abbott D.P., Haderlie E.C. (eds.) 1980. Intertidal invertebrates of California. Stanford University Press, Stanford, CA, USA.

Navia A.F., Cortés E., Jordán F., Cruz-Escalona V.H., Mejía-Falla P.A. 2012. Changes to marine trophic networks caused by fishing. Pp. 417-452. DOI: 10.5772/37787. In: Mahamane A. (ed.) Diversity of ecosystems. InTech Europe, Rijeka, Croatia.

DOI: $10.5772 / 2276$

Nieto-Navarro J.T., Zetina-Rejón M., Arreguín-Sánchez F., Arcos-Huitrón N.E., Peña-Messina E. 2010. Length-weight relationship of demersal fish from the eastern coast of the mouth of the Gulf of California. Journal of Fisheries and Aquatic Science 5 (6): 494-502. DOI: $10.3923 /$ jfas.2010.494.502

Orrell T.M. 2002. Order Perciformes; Suborder Percoidei; Centropomidae Snooks. Pp. 1286-1293. In: Carpenter K.E. (ed.) The living marine resources of the western central Atlantic. Vol. 2. Bony fishes part 1 (Acipenseridae to Grammatidae). FAO species identification guide for fishery purposes and American Society of Ichthyologists and Herpetologists Special Publication No. 5. FAO, Rome.

Pinkas L., Oliphant M.S., Iverson L.K. 1971. Food habits of albacore, bluefin tuna, and bonito in California waters. Fish Bulletin 152 (1): 1-105.

Robertson D.R., Allen G.R. 2008. Shorefishes of the tropical eastern Pacific: An information system. CD-ROM. Smithsonian Tropical Research Institute, Balboa, Panama. 
Sturges H. 1926. The choice of a class-interval. Journal of American Statistical Association 21 (1): 65-66. DOI: $10.2307 / 2965501$

Ulloa-Ramírez P.A., Patiño-Valencia J.L., GuevaraRascado M.L., Hernández-Ventura S., SánchezRegalado R., Pérez-Velázquez A. 2008. Peces marinos de valor comercial del estado de Nayarit, México. Instituto Nacional de Pesca, Bahia de Banderas, Nayarit, México.

White W.T., Platell M.E., Potter I.C. 2004. Comparisons between the diets of four abundant species of elasmobranchs in a subtropical embayment: Implications for resource partitioning. Marine Biology 144 (3): 439-448. DOI: $10.1007 / \mathrm{s} 00227-003-1218-1$

Yáñez-Arancibia A. 1978. Taxonomía, ecología y estructura de las comunidades de peces en lagunas costeras con bocas efímeras del Pacífico de México. Publicaciones Especiales Centro de Ciencias del Mar y Limnología, UNAM, Mexico.

Zetina-Rejón M.J., Arreguín-Sánchez F., Chávez A.E. 2003. Trophic structure and flows of energy in the Huizache-Caimanero lagoon complex on the Pacific coast of Mexico. Estuarine, Coastal and Shelf Science 57 (5-6): 803-815.

DOI: $10.1016 / \mathrm{S} 0272-7714(02) 00410-9$

Received: 22 July 2014 Accepted: 9 February 2015 Published electronically: 31 March 2015 